\title{
Professzorok és teológusok a forradalomban
}

\author{
Bertalan PÉter \\ Kaposvári Egyetem Társadalomtudományi Tanszék
}

\begin{abstract}
A tanulmány a református egyházban 1956-ban kibontakozó ellenállás folyamatát mutatja be korabeli források alapján. Vizsgálja, hogy az 1956-os forradalom és szabadságharc előtt milyen hatalmi mozgások játszódtak le a református egyház felső vezetésében. Az írás külön figyelmet fordít arra a tényre, hogy a forradalom napjaiban a teológiai akadémiák növendékei, valamint progresszív szemléletû́ professzorai, milyen jelentős szerepet játszottak az októberi napok sikerében.
\end{abstract}

\section{BEVEZETÉS}

A tanulmány primer forrásokra támaszkodva, a korabeli pártállami jelentésekre alapozva tárja fel és követi nyomon az 1956-ban a református egyház keretei között kibontakozó ellenállás jelenségét, valamint ennek kifutásaként bemutatja az egyházi elitváltás folyamatát. Analizálja, hogy az 19-ben a kommunista egyeduralom restaurálását, a monolit hatalomgyakorlási technikákat ismét előtérbe helyező kormányzat a forradalom alatti történéseket miként igyekszik „ellenforradalmi" tevékenységgé átminősíteni. Bemutatja azt a folyamatot, ahogy a hatalomaz egyházat 1956 novemberének végétől, a felső egyházi vezetés, valamint a református teológiák tanári karának belső megosztásával, totálisan ellenőrizni szándékozik.

A tanulmány a korabeli pártállami források csak manapság hozzáférhetôvé váló anyagaira támaszkodva következetesen érvényesített okadatolt, reflexív forráskritikával a történtek valószínúsíthetô verziójának feltárására törekszik. A kutatás során felhasznált források többsége úgynevezett soft forrás, elsősorban az Állami Egyházügyi Hivatal iratai. Értelmezésük a korszak politikai viszonyainak alapos ismeretét követeli meg.

A tanulmány bemutatja azt a bonyolult, komplex hatalmi játszmát, amely a pártállam és a református egyház megújulást kereső, a régi hatalomgyakorlási mechanizmusokat tagadó, az egész egyház érdekeit képviselő új vezetése között bontakozott ki 1956-ban. Az állampárti vezetés a hatalomtechnika és manipuláció, valamint a „divide et impera” elvének régi jól bevált módszereit igyekezett alkalmazni a régi status quo fenntartásának érdekében. A történelem azonban gyorsan túllépett az átalakulást akadályozni igyekvők szándékain, a forradalom 
ereje, sodró lendülete elsöpörte a régi egyházi vezetés utolsó bástyáit is. Az új demokratikus egyházi vezetés Ravasz László irányításával, a református teológia hallgatóira támaszkodva 1956 októberének végére megszilárdította az egyházon belüli hatalmi pozícióit. Ravasz László és vezetőtársainak a vidéki gyülekezetekre támaszkodó „lendülete” kitartott egészen 1957 kora őszéig, ezután gyorsan megvalósult a restauráció.

\section{EGYHÁZI REFORM, HATALOMVÁLTÁS KEZDETE}

A református egyházat az 1956-os forradalom és szabadságharc októberének dicső napjaiig az 1948-ban megkötött egyezmények következtében többségében a kommunista rendszert teljesen kiszolgáló vezetés irányította. Az 1956 őszén bekövetkező gyors változások viharként söpörték ki pozícióikból a régi vezetés képviselőit. A vezetésben történt átalakulás végiggyúrüzött az egész egyházszervezeten, a legkisebb parókiáig.

A megyei sajtó nagy terjedelemben foglalkozik a Somogyi Református Egyházmegye lelkésztestületének 1957. május 21-i tanácskozásával, az ott hozott határozattal. A lelkésztestület állásfoglalása szerint "a református egyház népe az október-november havi események próbái idején az Isten igéjére való figyelés tekintetében, tehát hitében és szeretetében megméretett és egy része hijával találtatott. Az Istentől az egyház számára elrendelt hitben felismert és közösen egyre inkább járni tanult úton meginogva az egyház népének számottevő része engedetlen útkereséssel próbálta az elmúlt esztendők hibáit orvosolni, és egyben a maga gondolatait és indulatait érvényre juttatni. Ezzel Jézus Krisztus dicsőségét nemcsak nem növelte, hanem botránkozásokat okozott az egyházban élők és az egyházon kívül élők előtt egyaránt. Örömmel állapítja meg az értekezlet, hogy - bár a Magyarországi Református Egyházban kisebb-nagyobb csoportokkal jelentős számban kerültek olyanok is a népi demokratikus rendszert alapjában megsemmisíteni akaró ellenforradalmi események sodrába, akiket az egyházi közvélemény kimondott szavaik és tetteik tekintetében irányt keresően figyelemmel kísért - ténykedésük nem okozott az egyház testén gyógyithatatlan sebeket."1

A lelkészértekezlet az állammal kötött egyezményt egyedüli járható útnak tekinti, és támogatja a kormányt. A törvénnyel ellenkezőnek nyilvánítja az 1956 elején megalakult, úgynevezett Országos Intéző Bizottságot, az általa elindított Megújulási Mozgalmat. Elítéli mindazon kezdeményezéseket és vállalkozásokat, amelyek az egyház 1956. október-november előtti vezetőinek félreállításáért folytak. Ezek közé sorolja a tisztújítások kierőszakolására irányuló törekvéseket is. Bereczky Albert püspököt, aki a forradalom előtt az Egyetemes Zsinat és Egyetemes Konvent elnöke volt, továbbra is tisztében levőnek tekinti. Ugyancsak ragaszkodását fejezi ki az értekezlet a megújuló egyházmegyét vezető Nyáry Pál esperes iránt. A határozatot a rendszer iránti húségnyilatkozat zárja.

Visszatekintve, az Egyházügyi Hivatal egy 1958-ban keletkezett helyzetfelmé-

\footnotetext{
${ }^{1}$ Somogyország, 1957. május 26. 7. o.
} 
rő jelentésében megállapítja, hogy a forradalmat megelőző időben a református egyházon belül fokozatosan kezdett megélénkülni, aktivizálódni a változást és változtatást akaró erők tábora. Mozgalomszerúen kezdték követelni és szervezni az egyházon belüli megújulást, amely kezdetben bizonyos hibák kijavítására, később a forradalom támogatására irányult. Egyre többen olyan „kéréssel” és követeléssel léptek fel, amely részben a korábban elmozdított vezetők visszahelyezését, valamint a fokozottabb hitéleti tevékenységet kívánták. ${ }^{2}$

A forradalmat megelőző enyhülés tette lehetővé, hogy az Egyházak Világtanácsának Központi Bizottsága, a protestáns egyházak nemzetközi szervezete (1956. július 28-augusztus 4.) Galyatetőn tartsa négyévenkénti ülését. A nemzetközi szervezet igen intenzíven támogatta - az egyházpolitikai jelentés szerint - a megújulási törekvéseket, amelyeknek élén Pap László, a Budapesti Református Teológiai Akadémia volt dékánja és Ravasz László, nyugalmazott püspök állt.

Pap László jó taktikai érzékkel, valamint ügyes diplomáciai lépésekkel elérte, hogy Ravasz László a tanácskozáson kedvező pozícióba kerüljön, valamint kezdeményezően tudjon fellépni.

Hatos Pál monográfiájában plasztikusan ábrázolja a kialakult egyházpolitikai helyzetet: "Ravasz szerint a kommunista államhatalom az egyházat az egyház által gyengitette meg leginkább úgy, hogy az egyház vezetóségét szembeállította Krisztus népével. Egyebekben Ravasz a Hitvalló Nyilatkozat érvelését követte, az egyházi diktatúra felszámolását kívánta, és újra megfogalmazta a követelést: Legyen szabad egyház a szabad államban. Ekkor már nem Rákosi volt a párt vezetője, s a viszonyok megváltozására jellemzö, hogy a Memorandumot Ravasz nemcsak Bereczkynek adta át személyesen Leányfalun, hanem az ÁEH vezetőinek is megküldte, és ezután a püspök szolgálati autóján vitték el Galyatetöre, az EVT konferenciájának helyszinére. A konferencia összes külföldi vendége Ravasz Lászlót faggatta, látható volt, hogy 75. életévéhez közeledve sem a múlt embere." (Hatos, 2016. 281. o.).

A református egyházban megindult reformfolyamat, a múlttal való ôszinte szembenézés szelleme hatotta át az 1956. augusztus 23-án, Balatonfüreden tartott lelkészi konferenciát is. Itt hangzott el Szíj Rezső beszéde. A felszólalás a református egyház bajainak gyökerét tárja fel: "A magyar alsópapság - a reformátusokról beszélek most - történelmünk folyamán mindig hü a néphez, áldozatok, üldöztetések árán is. Nincs még egy rétege a népnek, amelynek tagjai közül oly kevéssel lett volna baja a kormányzatnak, mint éppen a református magyar papság. Az állam tehát nem volt bizalmatlanabb irányunkban, mint általában más rétegekhez, az egyházi felsőbbség azonban még úgy sem bízott bennünk. [...] A mai egyházi kormányzat mindent megtett, hogy az alsópapságot szellemi sötétségben, tudatlanságban tartsa, a dászkálok színvonalára nyomorítsa, hogy minél engedelmesebb tömeget nyerjen benne, szolgálatkész réteget. [...] A föpapi, püspöki vezetés ne mitőlünk féltse a magyarságot és a népet, hiszen nekünk a világi fórumokkal sokkal kevesebb bajunk volt, mint saját

\footnotetext{
2Jelentés az egyházpolitikai helyzetről és javaslatok a helyzet javítására MM EH, Budapest, 1958. május 5. MNL OL, M-KS 288. f. 22. cs. 1958./4. ő. e.
} 
egyházi vezetőségeinkkel, akik mindent igyekeztek túllicitálni, ha volt rá ok, ha nem, s hogy miért, ezt is tudjuk, ha itt most nem mondhatjuk is el. De egyet ki kell mondanunk: nem bújhatnak ki a felelósségre vonás alól az állami szervekre vagy a kormányzatra való hivatkozással." (Szíj, 1995. 10-11. o.).

\section{RAVASZ LÁSZLó SZÍNRE LÉP}

Erdélyi körútjáról visszatérve Ravasz László hamar az események középpontjába, fő sodrába került. A forradalom kitörésének hírére a református egyház hívei és papjai is megmozdultak, a hivatalos hatalom megbénulva sodródott, bizonytalanul figyelve a felgyorsuló eseményeket. Ráadásul Bereczky Albert súlyos agyvérzést kapott, 1956 októberében már a hivatalos, addig a központi irányítás szándékainak megfelelően múködő egyházi lap az Út is lelkészek százainak protestáló, a megújulást, az eddigi egyházi vezetés távozását követelő leveleket, gyújtó hangú felhívásokat közölt. Az októberi napokban a forradalmi események forgatagában a teológushallgatók is kiemelkedő szerepet játszottak, ott voltak a demonstrációkon, kettővel közülük a hónap utolsó napjaiban humanitárius segélyakciójuk közben -- orvlövészek merényletei végeztek (Hatos, 2016. 283. o.).

A reformtörekvéseket össze kellett fogni. A Budapesti Református Akadémia épületében mintegy harminc egyházi személyiség 1956. november 1-jén megalakította a Magyar Református Egyház Országos Intézőbizottságát. Ez a bizottság felkérte Ravasz László nyugalmazott püspököt, hogy Kardos Jánossal - az 1948. szeptember 21-én lemondott főgondnokkal - vegye át a református egyház vezetését. Még ezen a napon Ravasz László rádiószózatában rendre, higgadtságra, nyugalomra intette a lakosságot (Balogh és Gergely, 1993. 314. o.). Mindez a Református Megújulási Mozgalom legalizálódását jelentette.

A Megújulási Mozgalom a reformszándékok megvalósításának akadályát jelentő egyházi vezetőket felszólította a lemondásra. A mozgalom demokratikus jellegét igazolja, hogy az egyház presbitériumainak $90 \%$-a szavazott a vezetés megújítása mellett. Az „újjászületést” segítette, hogy állami vonalon nem tudott a rendszer kellő erővel fellépni. Bereczky Albert súlyos betegsége, valamint a forradalom előtti helyzet és az utána visszatérő restaurációban aktív szerepet vállaló Péter János, a Tiszántúli Egyházkerület püspökének az egyházi vezetésből való kiválása a reformok képviselői számára szabaddá tette az utat. ${ }^{3} \mathrm{~A}$ Megújulási Mozgalom a forradalom fegyveres leverése után még intenzívebben folytatta tevékenységét. A világszervezetek - különösen az Egyházak Világtanácsa és annak vezetői - a külföldi sajtóban és rádióban egyrészt védték a mozgalom magyar irányítóit, másrészt a pártállammal lepaktáló régi egyházi vezetőket bírálták. Jelentős anyagi eszközökkel is segítették a református egyházat

\footnotetext{
${ }^{3}$ Péter János a külügyminiszter első helyettese 1958. 02. 19.-1961. 09. 13., külügyminiszter 1961. 09. 13.-1973. 12. 14., országgyúlési alelnök 1973. 12. 19-től. Minisztersége idejétől párttag. Lásd: Bölöny József (1978): Magyarország kormányai 1848--975. Akadémiai Kiadó, Budapest. 271. o.
} 
a forradalom után is. ${ }^{4}$

Az ancien régime egyházi vezetőinek magatartása sem egyértelmú. A református egyházban azért nehéz a „rendcsinálás” a politikai hatalom számára, mert Bereczky Albert püspök személye - még a hivatalos megítélés szerint is komolyan nehezíti a protestáns egyházakkal kapcsolatos rendeződést, derül ki a püspök egyházpolitikai tevékenységéről szóló jelentésből. ${ }^{5}$

Ha a közel azonos időben született forrásokat összehasonlítjuk és a tények kapcsolódási pontjait keressük, bonyolult összefüggések tárulnak fel előttünk. Az MM EH 1958. október 11-én kelt tájékoztatója Bereczky Albert püspök szerepével kapcsolatban így fogalmaz: „Az elmúlt évek során a nyílt egyházi reakció elleni harc közben a református egyházban két politikailag progresszív, minöségileg egymástól lényegesen különböző vonalvezetés alakult ki. Az első élén, amely őszintén és következetesen támogatja a párt politikáját, Péter János állt. A másodikat, amely mindenkor az egyház és a nyugati világszervezetek érdekeinek megfelelően, számítóan, taktikázva müködött együtt velünk, Bereczky Albert vezeti. Bereczky Albert és csoportja bizonyíthatóan a nyugati egyházi világszervezetek reakciós vezetöinek tanácsára mindenkor következetesen törekedett Péter János és közvetlen személyi munkatársainak először erkölcsi, majd egzisztenciális megsemmisitésére. A felszín alatti, többnyire burkolt harc ellenére az ellenforradalom mindkét politikai irányzat képviselöit kíméletlenül félreállította. Bereczky Albert és csoportja [...] szívósan küzdenek azért, hogy korábbi célkitüzéseiknek megfelelően Péter János embereivel végleg leszámoljanak. Óvatosan, de következetesen védelmezik az ellenforradalomban aktívan részt vevő, sőt az egyházi ellenforradalmi megmozdulásokban vezetö szerepet betöltő egyházi személyeket. Míg a politikailag szilárd embereket, bizonyos hibájukat felnagyítva üldözik, addig az ellenforradalomban kompromittált politikailag reakciós embereknél a megértés, megbocsátás szellemét gyakorolják. Az ellenforradalomban aktívan részt vett egyházi emberek közül egyet sem vontak felelősségre egyházi biróság elött. Pedig az egyezmény (a református egyház és a magyar állam által 1948-ban kötött egyezményről van szó - B.P.) szerint ez kötelességük. De név szerint sem bélyegeztek meg senkit (Ravasz László, Pap László stb.), annak ellenére sem, hogy ezt többször kértük írásban is a megfelelő bizonyitékok átadásával egy időben."' ${ }^{\text {A }}$ református egyházon belül tehát komoly hatalmi harc indult meg, amelyet az EH figyelemmel kísért és kihasznált.

\section{KARL BARTH vÉLEMÉNye}

Karl Barth, a neves svájci teológus is követte a református egyház helyzetének

\footnotetext{
4Jelentés az egyházpolitikai helyzetről és javaslatok a helyzet javítására Budapest, 1958. 05. 05. MM EH MNL OL, M-KS 288. f. 22. cs. 1958./4. őe. M

${ }^{5}$ Jelentés a Politikai Bizottság 1958. 06. 10-i , az állam és az egyházak közötti viszonyra vonatkozó határozatának végrehajtásáról MM EH Budapest,1958. 09. 13. MNL OL, M-KS 288. f. 22. cs. 1958./4. ő. e. M

${ }^{6}$ Tájékoztató a Bereczky Albert református püspökkel kapcsolatos egyházpolitikai és személyi kérdésekről MM EH Budapest, 1958. 10. 11. MNL OL, M-KS 288. f. 22. cs. 1958./4. ő. e. M
} 
alakulását az 50-es években. Ennek bizonyítéka az a terjedelmes nyílt levél, amelyet 1951. szeptember 16-án Bereczky Albertnek írt. Felhívja Bereczky figyelmét arra, hogy a református egyház vezetése megegyezett a magyar kormánnyal, a magyar sajtó azonban csak propagandisztikus információkat ad erről. Igyekszik jó megvilágításban feltüntetni az egyezmény református egyházra háruló következményeit. Kétkedő kérdéseket fogalmaz meg és álláspontját az alábbiakban fejti ki: „Hogyan történhetett az, hogy Önök ezt a keleti propagandát vállalják, és keresztyéni és egyházi áldásuk alá helyezik azt a stockholmi békemozgalomnak nevezett vállalkozást a békegalambbal, amelynek körmei vannak?! Megfelel Jézus Krisztus egyházának, ha mindenbe beleegyezik, amit kormányuk akar és tesz? [...] Mint keresztyén nem vállalhatom Önnel ezt a felelösséget. Nagyon kérem, figyeljen arra, hogy a magyar egyház és egyházközösségei olyan fordulóponthoz jutottak, amelyen előbb-utóbb szerencsétlenség következhet be." (Tibori, 1996. 37-38. o.).

A Budapesti Teológiai Akadémia által megrendezett centenáriumi ünnepségekre az Egyházak Világtanácsának több vezetője 1955-ben Budapestre érkezett. Azonban Karl Barth, akit még 1951-ben mélyen felháborított a sárospataki teológia bezárása, ismét visszautasította a rendezők meghívását. A kommunista államhatalom a kirakatpolitika látszatát, valamint a "divide et impera” elvét alkalmazta a nyugati egyházi vezetés és közvélemény rokonszenvének elnyerésére, ezért Martin Niemöller német antifasiszta teológust díszdoktori címmel tüntette ki. A nyugatról érkezett egyházi vezetők számára azonban némileg világosabb lett a magyarországi egyházpolitikai helyzet, amikor Péter János invitálására Debrecent is meglátogatták. Itt a Teológiai Akadémián tizenöt hallgató ügyeletet tartott, tájékoztatva a külföldi egyházi vendégeket arról, hogy kis idővel megérkezésük előtt az ÁVH két tiszántúli lelkészt letartóztatott. Az állami erőszakszervezet által foganatosított az egyéni szabadságot súlyosan korlátozó intézkedés oka, hogy a lelkészek a püspöknél beadványban tiltakoztak a rájuk kényszerített, a termelőszövetkezeti mozgalmat népszerúsítő prédikációk elmulasztása miatt (Hatos, 2016. 279.).

Szíj Rezső beszéde is igazolja a Karl Barth-i jóslatot. A szerencsétlenség bekövetkezett. A református egyház vezetése elszakadt a hívektől, a papságtól.

A svájci teológus ezután öt évig hallgatott. A Magyarországon történtekről azonban folyamatosan értesül. A különböző utakon, főleg lelkészek által küldött levelekből pontosan informálják a református egyház helyzetének további romlásáról. 1956 májusában újabb levélben fordul Bereczkyhez: „Én itt (Svájcban) egészen kevés emberrel beszéltem - írja Barth -, de az általános kép, amellyel itt az emberek rendelkeznek a "vasfüggöny mögötti "állapotokról még sötétebb. Ha csak annyi az igazság, amennyit nekem megirtak, akkor is meg kell gondolni, hogy Magyarországon ezeket a nehézségeket nem szétverni, hanem megszüntetni kell. Az Önök egyházi szavahihetösége és azzal együtt a magyar református egyház ökumenikus szavahihetósége is kockára van téve." (Pap, 1992. 331. o.). Karl Barth állásfoglalásai a protestáns egyházak számára a lelkiismeret szavát jelentették. Érthető, hogy Bereczky Albert fokozatos elbizonytalanodásához jelentősen hozzájárultak. 
Bereczky Albert 1956. november 1-jei lemondását követően, - amelyet az adott körülmények között sem a református egyház vezető testületei, sem az állami vezetés elfogadni nem tudnak - interregnum keletkezett. A helyzetet csak Ravasz László menthette meg, aki 1956. november 1. - 1957. április 12. között ideiglenesen átvette a református egyház irányítását, de nem tekintette magát püspöknek (Balogh és Gergely, 1996. 126. o.).

\section{1956 NOVEMBERE}

Hatos Pál monográfiája kiválóan segíti a novemberi események pontos rekonstruálását.

„November 1-jén a közhangulat nyomására- hangsúlyozottan csak ideiglenesen, a törvényes tisztújitásig- elvállalta az egyház lelki vezetését, a megalakuló Országos Intéző Bizottság Pap Lászlóval történö együttes irányitását. [...] Csatlakozott hozzájuk Kardos János, akit az egyház 1948 őszén, törvényesen megválasztott, de akadályoztatott világi vezetőjének tartottak. Ekkor már sorra érkeztek a hírek a kollaboráns egyházi vezetők és tisztségviselők lemondásáról. Másfél nap alatt összeomlott mind a református, mind az evangélikus egyház kommunista államhatalom által kinevezett teljes vezetése. Ugyanaznap este Tildy Zoltánnak, a Nagy Imre-kormány államminiszterének kérésére Pap László után Ravasz László is rádióbeszédet mondott, csodálattal és hódolattal adózott a nemzeti felkelés hőseinek, felszólitotta a lelkészeket és minden reformátust, hogy a nemzeti egység, a társadalmi igazságosság és a testvéri szeretet szolgálatában példamutatóan elöljárjanak, de higgadtságra, a rend megörzésére intett, és elutasitott minden restaurációs kísérletet: Még gondolni se merjen senki az elmúlt korszakok rendszereinek visszaállitására! Beszédét másnap címoldalon közölte a forradalom viharában életre hívott új lap a reformáció, de a lap csupán egy számot ért meg, néhány nap múlva, november 4-én a bevonuló szovjet csapatok vérbe fojtották a forradalma. [...] Az egyházi megújulás mozgalma azonban hónapokkal élte túl a szabadságharc leverését. November 13-án az Országos Intéző Bizottság Ravasz László által aláirt tömör programot írt, választ kérve a gyülekezetektől. A mintegy 1200 magyarországi református gyülekezet túlnyomó többsége, több mint kilencszáz presbitériumi határozattal, irásban erösítette meg támogatását és csatlakozását. [...] Ennek ellenére- vagy éppen ezért - az Országos Intéző Bizottság, illetve a belőle 1956. december 21-én új nevén alakult Református Megújulási Mozgalom hamarosan a teljes visszarendeződést kitüző kádári hatalom célkeresztjébe került." (Hatos, 2016. 281-282. о.).

Bereczky 1958. május 20-tól augusztus 8-ig betegségének kezelése miatt három hónapig pihent Svájcban. Itt találkozhatott Karl Barthtal. A vele folytatott beszélgetés tovább erősíthette óvatosságát, amellyel a rendszerrel szemben álló egyházi ellenzék elleni retorziókat késleltetni igyekezett. Ezt igazolja az EH tájékoztatója is, amely szerint a Bereczky Albertnek felrótt búnök nem a Svájcból való hazaérkezés után kezdődtek, hanem akkor fejeződtek be. ${ }^{7}$

\footnotetext{
${ }^{7}$ Tájékoztató a Bereczky Albert református püspökkel kapcsolatos egyházpolitikai és személyi
} 
Karl Barth levelei és Szíj Rezső kemény kritikája bizonyítja, hogy a református egyház vezetése már az 50-es évek elején kényszerhelyzetben volt. Az állami akaratnak való megfelelés, a nyugati protestáns egyházi világszervezetek, az alsópapság elégedetlensége azt a belső küzdelmet indította meg az egyházban, amely az 1956-os forradalom hatására nyílttá vált. A Bereczkyvel kapcsolatos pejoratív, több esetben durva, személyeskedő hangvételú minősítésben benne van a tájékoztatót aláíró Horváth Jánosnak, az EH elnökének és Miklós Imrének, az EH elnökhelyettesének személyes ellenszenve és az állami vezetés részéről megnyilvánuló neheztelés. Közvetve kifejeződik benne a jelentéshez adatokat szolgáltató, Bereczky lejáratásában személyesen érdekelt református egyházi vezetők véleménye is. A kormány 1958-ra már érzett magában annyi erőt, hogy Bereczkytől megváljon, aki sem egészségi, sem mentális szempontból nem felelt meg az új feladatoknak, az „engedetlen, lázadó” egyház megzabolázásának. Bereczkynél sokkal agilisabb, a kemény restaurációt következetesebben kiszolgálók álltak a rendelkezésre, akiket az ekkor már világi pályán magas pozícióba jutott Péter János (az Elnöki Tanács tagja, a Kulturális Kapcsolatok Intézetének elnöke) „kívülről” támogatott. Nemcsak támogatott, hanem a restauráció gyakorlati programját is megfogalmazta: „Mit kell most tenni? [...] Keresni kell a megbánás helyét. [...] Aki a törödött szívet nem veti meg, annak az Úr irgalmában reménykedve kell keresni a megbánás helyét azért a lázadásért, amelyet elkövettünk, amit engedtünk elkövetni a számunkra meghirdetett evangélium ellen. Olyan embereket kell az élre állítani, akikben megvan a kormányzás ajándéka. Vagyis akik értik, hogy mi történik az egyház körül, akik tudják, hogy milyen terepviszonyokon kell az egyház útját előre vinni. A bosszúállás lendülete nélkül komolyan felelősségre kell vonni, aki a romlásért felelős. [...] Az egyházért komolyan fel kell lépni a reakció minden maradványa, tünete, személyi képviselője, tanítása, megigéző viselkedése ellen." (Tibori, 1995. 408-409. o.).

\section{DiVIDE ET IMPERA, VISSZARENDEZŐDÉS}

Az Egyházügyi Hivatal a református egyházon belüli interregnumot a maga javára használta fel. Pontosan felméri a terepet, erről tájékoztató jelentés készül. Ennek ismerete azért fontos, mert megrajzolja az állami beavatkozás koreográfiáját. Az egyház „belügyeibe” való beavatkozásra megvolt az indok, de a szemben álló erők küzdelme megkönnyítette a pártállam politikusainak dolgát. Bereczky Albert ellenfele Békefi Benő, Péter János egyik legközvetlenebb munkatársa volt. A nyíregyházi esperest a debreceni teológiáról helyezték át a pesti teológiára. Hat évet dolgozott aktív teológia tanárként. Ellenfelei azzal vádolták, hogy szakmailag felkészületlen. Békefi Benőt az MSZMP Szabolcs Megyei Pártbizottsága támogatta, és szorgalmazta védencének rehabilitálását. A budapesti teológiára való áthelyezése a forradalom előtt azért történt, hogy felszámolják a reformokat, a változásokat követelő ellenállás szellemi gócait. Ez

kérdésekről. MM EH Budapest, 1958. 10. 11. MNL OL, M-KS 288. f. 22. cs. 1958./4. ő. e. M 
formailag megfelelt mind az egyházi, mind az állami törvényeknek. Bereczky Albert visszatérése után összehívta a konventi elnökséget, amelynek rajta kívül még három püspök és a főgondnok volt a tagja. Bereczky megkérdőjelezte az áthelyezés szabályosságát és lemondással fenyegetőzött. A konventi elnökség ezzel a zsarolással szemben egyhangúlag megvédte az eljárás „törvényességét". Mindez azért Bereczky elutazása után vetődött fel, mert júniusban ért véget a teológiai év, és a tanári áthelyezések vagy elbocsátások is június, július hónapban történnek. Az Egyházügyi Hivatal minden érdekelttel - Esze Tamás fógondnok, Bartha Tibor debreceni püspök, Czeglédi István a budapesti teológia dékánja megbeszélte a kérdést, s az ügy ezután került az igazgatói tanácsülés elé. ${ }^{8}$

A bonyolult hatalmi küzdelem azt bizonyítja, hogy az állam mozgástere 1958-ban is még aránylag szúk volt, a református egyház felső vezetésének ellentéteit óvatosan kellett még kezelni, hiszen a Ravasz László vezette Megújulási Mozgalom elfojtásában mindkettő érdekelve volt. A konvent állásfoglalása azt dokumentálja, hogy Péter János hívei megszilárdították helyzetüket az egyház vezetésében.

A jelentés nem hallgatja el azt sem, hogyan próbálja Bereczky egykori harcostársának, Péter Jánosnak a táborát gyengíteni. A püspök 1956 őszén Fekete Sándort Pécsre helyezte, amit ő nem fogad el. Ezután az Egyházügyi Hivatal tudtán kívül Bereczky egyházi bíróság elé állította a volt budapesti esperest, Péter János közvetlen munkatársát. (A forrás szerint - B.P.) Az ítélet értelmében a papi palást elvesztése példátlanul kemény büntetésnek számított. Politikai és erkölcsi rehabilitálását a hatóság szorgalmazta, mert véleménye szerint az már régóta indokolt. Ennek megtörténte után Fekete Sándor nem vállalt egyházi szolgálatot, csak elvileg kapta vissza a palástot. 1956 májusa óta a Magyar Rádió munkatársa volt.

Szó esik még dr. Kádár Imre volt konventi főtanácsosról, aki prominens tagja Péter János munkatársi körének. Ugyanakkor a Theológiai Szemle főszerkesztője és a Budapesti Református Teológia tanára. Lelkészképesítése nincs, de Bereczky elismeróen nyilatkozott róla.

A helyzetfelmérés bemutatja a református egyház vezetésének megosztottságát, amit azzal indokol, hogy a hatalomért küzdő két tábor egyaránt ellenséget látott a Megújulási Mozgalom vezetőiben. Ravasz László mellett dr. Pap László, a Budapesti Református Teológia volt dékánja, a református egyház közismert egyházi vezetője volt. Nemcsak itthon, Nyugaton is ismerték. Az Egyházak Világtanácsa Központi Bizottságának tagjaként képviselte a magyarországi református egyházat. A forradalom után a pártállam nem engedte vissza tanári és dékáni állásába. Bereczky Albertre való tekintettel „,körültekintően”, viszonylag lassan számoltak le vele. A hatalom tartott tóle, mert kijelentette, ha egyházi bíróság elé állítják, igen sok adatot hoz nyilvánosságra. Ezekkel valóban ren-

${ }^{8}$ Tájékoztató a Bereczky Albert református püspökkel kapcsolatos egyházpolitikai és személyi kérdésekről. MM EH Budapest,1958. 10.11. MNL OL, M-KS 288. f. 22. cs. 1958./4. ő. e. M 
delkezett, és kompromittálni tudta volna Bereczkyt és más hozzá közel álló személyeket. Mind az Egyházak Világtanácsának vezetői, mind Bereczky tudtak erről, és ezért "védték".

Találkozunk még a dokumentációban a Megújulási Mozgalom egy kevésbé ismert, de fontos személyiségének, Nagy Barnának a nevével. Ő is a Református Teológia tanára volt Budapesten. 1956. november végén levelet írt Török István debreceni teológia tanárnak, amelyben megkérdezte kollégájától, miért nem mondja el véleményét. Török István 1956. december 12-én egy papi gyúlésen élesen elítélte Bereczky és Péter János egyházpolitikáját. 1957 elején letartóztatták, de betegsége miatt később kiengedték. Nagy Barnát lemondatták teológiai tanári rangjáról, de ennek fejében teológiai munkáin dolgozhatott régi fizetése mellett. Ezt az ügyet így sikerült zavarmentesen rendezni. ${ }^{9}$

Bereczky püspök nem csak a vezető pozíció megtartásáért küzdött, és ellenfelei sem csupán pozícióharcot folytattak. Dr. Török István értékelése szerint „Bereczky Albert egyike volt nálunk a nagyon gyér számú ellenállóknak. (Ez 1944-re vonatkozik - B.P.) Ő a "felszabadultam" szót még prófétai értelemben használta. Úgy fogadta el az utóbbi világháború kimenetelét, mint Isten irgalmas ítéletét. Isten kegyelmet gyakorolt rajtunk, könyörült a sorozatos embertelenségek hallgatólagos eltürése, olykor pártolása miatt pusztulásra érett egyházon. Bereczky nagy bünbánathirdetőink egyike, éppen olyan időkben, amikor mindenki a sorsforduló gondjaival, sérelmeivel, örömeivel volt elfoglalva, és kevés készség maradt a bünbánatra. Szóban-írásban hangot adott annak is: nem ért a fordulat óta sem mindennel egyet, ami körülötte történik, de tőle nem is kívánja senki, hogy mindent helyeseljen. Amikor a győzők egymással meghasonlottak, $s$ a forró háborút folytató hidegháború eredményeként a vasfüggöny kettéválasztotta Európát, ki merte mondani, mi nem Kelet és Nyugat határán, hanem Keleten vagyunk. Ha ezt nyugati atyánkfiai szemére vetették, Jaltára hivatkozott, ahol a nyugatiak már 1945 februárjában, a mi megkérdezésünk nélkül, beleegyeztek országunknak a keleti érdekszférába való besorolásába, s mi Isten kezéböl elfogadva ezt a döntést, megpróbáljuk itt az egyház keskeny, de ígéretes útját járni." (Török, 1990. 104. o. ).

Ez a keskeny út a szolgálat útja. Dr. Török István szerint az „ecclésia servans és az ecclésia servilis" fogalmai között vezető keskeny ösvény (Török, 1990. 104.). A finom distinkciót a teológus professzor a Megújulási Mozgalomtól veszi át, amely keményen bírálta a református egyház vezetésének az állam előtti behódolását: „Egyházunk, noha szolgálat volt a jelszava, a valóságban a világi felsőbbséget kiszolgáló, a világ módszereit átvevo", parancsoló, költekezö, reprezentáló egyház típusa felé sodródott az elmúlt években."10

A „szolgálat teológiája” Karl Barth nevéhez füződik. A neves svájci teológus a protestáns egyházak felelősségére hívta fel a figyelmet, hogy szálljanak szembe a fasizmus keresztényellenes, antihumánus politikájával. Kétszer - 1936-ban és

\footnotetext{
${ }^{9}$ Tájékoztató a Bereczky Albert református püspökkel kapcsolatos egyházpolitikai és személyi kérdésekről. MM EH Budapest, 1958. 10. 11. MNL OL, M-KS 288. f. 22. cs. 1958./4. ő. e. M

${ }^{10} \mathrm{~A}$ magyar református egyház útja (A Református Megújulási Mozgalom programja). MNL ÁEH Arch. XIX-A-21-C-310/32. 102. d.
} 
1948-ban - is megfordult Magyarországon. Protestáns teológusaink jól ismerték. Bereczky Albert is átvette a Karl Barth-i teológia krisztusi alaptételét, amely szerint az egyháznak az emberiség érdekeit kell szolgálnia. A demokrácia álarcában jelentkező diktatúra is a fasizmusellenesség jelszavával akarta maga mellé állítani a tömegeket. A Bereczky-féle teológia így talált közös nevezót a kezdetben emberarcúnak látszó diktatúrával (Poór, 1986).

A diktatúrák a "langyos" magatartást, politizálást is megtorolják, s „elkötelezett" állásfoglalásra kényszerítik ellenfeleiket és az együttmúködésre hajlókat. Az 1956-os forradalmat követó megtorlás az egyházakat, így a reformátust is aránylag késő́n érte el. Az 1956 decemberében kezdődő első letartóztatási hullám még nem érintett senkit. Csak 1957 februárjától kezdődött meg a rendőri szervek érdeklődése a református lelkészek iránt. Barcza József kutatásainak eredménye szemléletesen igazolja, hogy a református felekezet is megszenvedte a kádári pártállam egyházpolitikáját. Nemcsak a lelkészek, hanem „civilek” is váltak áldozataivá a meghurcoltatásoknak (Barcza, 1994. 66. o.). Ennek nagyon kézenfekvő okai vannak. A legújabb 1956-ról szóló munkák szerint a légüres térben mozgó FMPK, illetve Kádár János a legaktívabbakkal kezdte, többre nem futotta alig meglévő erejéből, apparátusától. De közrejátszott ebben az ideológiai bizonytalanság is. Még nem vált egyértelmúen uralkodóvá az „ellenforradalom” - tézis, nem tudták milyen körre kívánják azt kiterjeszteni.

Az Egyházügyi Hivatal már 1956. november 28-án hírt adott magáról a Népszabadságban. A közlemény szerint az állam és az egyházak között felmerülő kérdéseket a jövőben is a tárgyalások és megegyezések útján kell rendezni. A rendezést jelentő tárgyalások a református egyház vezetésének megtörését, a diktatúra elfogadását, a Megújulási Mozgalom felszámolását jelentették. Ebben Bereczky Albert és Péter János egyaránt szerepet vállalt (Barcza, 1994. 94. o.).

A megosztó politikának fó célja, hogy a maga oldalára állítsa az egyházi vezetőket, és szembeállítsa a különböző egyházakat. Az 1957. december 31-i állami kitüntetések, amelyeket a felekezetek vezetói kaptak, a közvéleményben nagy feltûnést keltettek. Barcza József a Confessio címú egyházi folyóiratban közzétett tanulmányában értékeli a történteket. A 23 kitüntetett közül hét volt református (Bereczky Albert püspök, Bartha Tibor, Pákozdy László professzorok, Hajdú Péter, Szamosközi István esperesek, Nyáry Pál püspökhelyettes, Huszár Kálmán konventi csoportvezető). Itt a nevek kiemelése azért fontos, mert közülük senki sem volt annak a vegyes bizottságnak a tagja, amely 1956 decemberében a református egyház képviseletében folytatott tárgyalásokat az EH-val. E vegyes bizottság tagjai - Győry Elemér püspök, Buza László egyházkerületi főgondnok, Gaál István, Büki Zsigmond esperesek és Dienes István egyházmegyei gondnok - közül senki sem kapott állami elismerést. Ugyanúgy hiányoztak a névsorból azok is, akik a Rákosi-féle diktatórikus rendszer legismertebb kiszolgálói voltak, és ezért egyáltalán nem élveztek közbizalmat (Kádár Imre, Finta István, Békefi Benő). Jól átgondolt protokoll-lista volt ez. Barcza véleménye szerint a kitüntetettek felekezeti arányainak elemzése fontos tanulsággal is jár. A 7 
református mellett 11 római katolikus, 2 evangélikus, 1 görög katolikus, 1 baptista és 1 izraelita egyházi vezető kapott magas állami kitüntetést. Mondhatjuk, hogy összeállt egy belső ökumenikus kép. Szembeszökő az aránytalanság, ha figyelembe vesszük a legutolsó olyan népszámlálási adatokat, amelyek még feltüntetik a lakosság felekezeti hovatartozását. (Magyarország összlakosságából kereken 70\% volt római katolikus, 20\% református. Itt viszont az arányszám 7:2 helyett 11:7 lett.) Az aránytalanságból Barcza József arra következtet, hogy az állam leginkább a református egyházat tüntette ki, részint korábbi „érdemeiért”, részint megelőlegezett bizalma miatt (Barcza, 1994. 95. o.).

Barcza professzort a múlt kritikus feltárásának szándéka vezeti. Az az indulati többlet, amely a tanulmány soraiból érződik, a Kádár-rendszernek behódoló református egyházi vezetés és az állam között 1958 után kialakult „,jó viszonynak" szól. Ezt Barcza József el- és megítéli. A többi egyházra való hivatkozást csupán az adott helyzet reális bemutatása miatt tartotta szükségesnek.

Bereczky Albert nem „hálálta” meg a kitüntetést, mert az állam és a református egyház közti párbeszédben a személyi kérdésekben középutas álláspontot foglalt el. 1958. október 7-én püspöki szolgálatának 10. évfordulója alkalmából tartott beszédében azt mondta, hogy „sürgő rendeznivaló a személyi kérdések olyan becsületes elintézése, amely úgy az egyháznak, mint az államnak jogos igényét és egymással való békés viszonyát szolgálná. Mert a könnyebb ellenállás csábító kísértése mindig jelentkezik és lehet rövid lejáratra olyan alkalmasnak látszó embereket állítani vezető helyekre, akiknek hiányzik az egyházi hitele, s akiknél előbb-utóbb bebizonyosodik az a tétel, hogy nem mindig a kényelmesebb út a jó, és nem mindig a kényelmes egyházi emberek a hüséges és megbízható emberek. Talán szabad volt most nekem ezt a szempontot, mint kérdést a kormányzat felé is kifejezni." A püspök minden befolyását latba vetette, hogy az őt „balról” előzni akarókat ne engedje a hatalom közelébe. Állásfoglalása a párt legfelső vezetése számára is kellemetlen volt, ezért Bereczkyvel személyesen akartak tárgyalni. Az EH vezetői - Horváth János és Miklós Imre - Péter Jánosban jobban bíztak, ezért kérték, hogy az ő véleményét is hallgassa meg Kádár János vagy Münnich Ferenc. ${ }^{11}$

\section{Restauráció}

A politika kényszerpályán mozog. Ezt bizonyítja, hogy Bereczky, akit bár 1958-ban visszahelyeztek a püspöki székbe, a hivatalos egyházpolitika számára gondot jelent, ha a protestáns egyházakkal való viszony rendezését simábbá akarják tenni. Ennek oka az, hogy ő a legidősebb püspök, s a Zsinat és a Konvent lelkészi elnökeként nemcsak a saját, hanem a többi protestáns felekezet helyzetét is befolyásolja az állammal való viszonya. A hatalom szorgalmazza nyugdíjazását, de csak az országgyúlési választások után tartja aktuálisnak.

\footnotetext{
${ }^{11}$ Tájékoztató a Bereczky Albert református püspökkel kapcsolatos egyházpolitikai és személyi kérdésekről. MM EH Budapest, 1958. 10. 11. MNL OL M-KS 288. f. 22. cs. 1958./4. ő. e. M
} 
Az erőszakos lemondatás látszatát is el akarják kerülni, ezért betegségre való hivatkozással kéri nyugdíjazását. Külön ügyel a politikai vezetés arra, nyugdíjba vonulása ne politikai színezetû́ legyen. ${ }^{12}$

Míg Bereczky az állami vezetés számára partnerből a helyzet szülte kényszer miatt provizórikusan megtúrt ember lett, addig a Megújulási Mozgalom vezetői ellenségnek számítottak. Ravasz Lászlót nem volt nehéz ismételten félreállítani, hiszen a sok családi tragédiát megélt idős püspököt könnyû volt visszaparancsolni leányfalui magányába. ${ }^{13}$

Ravasz László legbizalmasabb munkatársa, Pap László már több gondot okozott, hiszen fiatal kora ellenére nagy tekintélynek örvendett, s ezt a pártállam vezetői is akceptálták. Horváth János, az EH elnöke először megpróbált tôle nyilvános búnbánatot és húségnyilatkozatot kicsikarni. Ố azonban sem a fenyegetéseknek, sem az ígérgetéseknek nem hajolt meg. Csupán annyiban engedett a külső nyomásnak, hogy 1957. január 31-i hatállyal lemondott - a tanári kar és az ifjúság tiltakozása ellenére - teológiai dékáni címéről. Az állam arra várt, hogy Pap László beadja a derekát, de mivel ez nem következett be, tanári múködésétől a hozzájárulást megvonta. A Konvent Elnöksége 1958. július 1-jei hatállyal szüntette meg professzori állását. Ezután Zuglóba helyezték segédlelkésznek, de még a fóvárosban való tartózkodását is veszélyesnek ítélve egy vasútállomás nélküli szórványgyülekezetbe, a somogyi református egyházmegyéhez, a közigazgatásilag Tolna megyéhez tartozó Murgára küldték. Hiába hívta az utrechti egyetem 1957. november 29-től kezdve többször is a katedrájára, kiutazási engedélyt nem kapott. A református egyház legfelső vezetésének később módja lett volna arra, hogy a lelkész sorsán változtasson, de haláláig (1983) teljes elszigetelésére törekedett (Barcza, 1990. 89. o.).

Ravasz László így értékeli a restauráció folyamatát, benne Bereczky Albert sorsát: „Az egyház és az állam viszonya korántsem volt idilli és harmonikus, amilyennek feltüntetik. Az állam és a legfóbb vezetés közt az volt, de ez keltette fel az általános bizalmatlanságot az egyházi vezetőség iránt, s mi tudjuk a legjobban, hogy ez a vezetöség - tisztelet a kivételnek - maga is böven adott okot a bizalmatlanságra. Semmi sem bizonyítja ezt jobban, mint az a küzdelem, amelyet Bereczky Albert néhány prominens (kiemelkedő) munkatársával vívott." (Ravasz, 1992. 390.). Ravasz László megítélése is azt bizonyítja, hogy Bereczky „középutassága” volt az az alapvető ok, amit az állami vezetés elfogadni nem akart.

A személyi feltételek megteremtése volt az állam számára a legfontosabb, hiszen az így kialakuló egyházi vezetés már készségesen együttmúködött a végső cél elérésében, az egyház közigazgatásának centralizálásában. 1960. október 6-

\footnotetext{
${ }^{12}$ Jelentés a Politikai Bizottság 06. 10-i, az állam és az egyházak közötti viszonyra vonatkozó határozatának végrehajtásáról. MM EH Budapest, 1958. 09. 13. MNL OL, M-KS 288. f. 22. cs.1958./4. őe. M

${ }^{13}$ Ravasz László Emlékezéseim címmel (1992) történelmi és irodalmi szempontból egyaránt értékes memoárjában bemutatja a Megújulási Mozgalom célkitúzéseit, a református egyházban kibontakozó küzdelmeket 1956-1957-ben, s a pártállam beavatkozásának következményeit.
} 
tól a Zsinat és a Konvent Elnöksége azonos. Ez megkönnyítette az államhatalom számára, hogy a református egyház belső életét a maga igényeinek megfelelően ellenőrizze, befolyásolja. (Barcza, 1994. 103. o.)

\section{ÖssZEGZÉs}

Az „oszd meg és uralkodj” pártállami politikája a 60-as évek közepére teljesen megtörte a református egyházban 1956-ban megjelenő megújulási törekvések lendületét. Az egyházon belüli centralizáció, a hatalmi hierarchiában szigorúan alkalmazott alá-fölé rendeltségi viszonyok megnehezítették az alulról, a társadalommal közvetlenül érintkező, a parókiákon szolgálatot teljesítő lelkészi réteg demokratikus törekvéseinek érvényesülését.

Az atomizált, egymással hálózati kapcsolatban nem lévő, személyükben elszigetelt lelkészek politikailag, anyagilag kiszolgáltatva csak hatalmas nehézségek árán tudták fenntartani és múködtetni egyházi szervezeteiket. Ennek eredményeképpen a lakosság hitéleti aktivitása vidéken folyamatosan csökkent. Ez a tendencia tökéletesen megfelelt a Kádár-rendszer egyházakkal szemben gyakorolt hatalomgyakorlási módszereinek. A nagypolitika kirakatában az állam és a történelmi egyházak felső vezetése között látszólag a közeledés, egymás gondolatainak megismerésére törekvés álságos politikájának lehetünk tanúi, a mélyben a hit eróziójának lassú, de kíméletlenül végbemenő folyamatát láthatjuk.

\section{LEVÉLTÁRI FORRÁSOK}

\section{Magyar Nemzeti Levéltár (MNL OL)}

M-KS 288. f. 22. cs.1958./4. őe. Jelentés az egyházpolitikai helyzetről és javaslatok a helyzet javítására. MM EH, Budapest,1958. 05. 05.

M-KS 288. f. 22. cs.1958./4. őe. Jelentés a Politikai Bizottság 1958. 06. 10-i , az állam és az egyházak közötti viszonyra vonatkozó határozatának végrehajtásáról. MM EH, Budapest,1958. 11. 13.

M-KS 288. f. 22. cs.1958./4. oee. Tájékoztató a Bereczky Albert református püspökkel kapcsolatos egyházpolitikai és személyi kérdésekről. MM EH Budapest,1958. 10. 11.

M-KS 288. f. 22. cs.1958./4. őe. Jelentés a Politikai Bizottság 06. 10-i, az állam és az egyházak közötti viszonyra vonatkozó határozatának végrehajtásáról. MM EH Budapest,1958. 09. 13.

Magyar Nemzeti Levéltár, Állami Egyházügyi Hivatal Archívuma (MNL ÁEHA):

XIX-A-21-C-310/32. 102. doboz A magyar református egyház útja (A Református Megújulási Mozgalom programja)

XIX-A-21-C-410/8/1967. 124. doboz 
XIX-A-21-C-410/1/1957. 124. doboz

XIX-A-21-C-410/8/1967. 124. doboz A magyarországi evangélikus egyház mai helyzete, problémái és feladatai.

XIX-A-21-C-41/8/1967. 124. doboz A magyarországi evangélikus egyház mai helyzete, problémái és feladatai, Budapest,1957. 01. 27.

XIX-A-21-C-41/14/1969. 124. doboz Feljegyzés, Budapest, 1969. 09. 09.

\section{FelhasZnÁlt IROdALOM}

Balogh Margit és Kollega Tarsoly István (1996, szerk.): Egyházak a szovjet rendszerben (1945-1989). Magyarország a XX. században. II. kötet. Babits Kiadó, Szekszárd.

Balogh Margit és Gergely Jenő (1993): Egyházak az újkori Magyarországon 1790-1992. Kronológia. História MTA Történettudományi Intézete, Budapest.

Balogh Margit és Gergely Jenő (1996): Egyházak az újkori Magyarországon 1790-1992. Adattár. História MTA Történettudományi Intézete, Budapest.

Barcza József (1994): Az 1956-os forradalom megtorlása a Magyarországi Református Egyházban . Confessio,1. 63-78. (1994/2)

Barcza József (1994): Megtorlások a gyakorlatban. Confessio, 18. 2. sz. 63-78.

Barcza József (1990): Pap László (1908-1983). Confessio, 14. 1. sz. 87-90.

Barth Károly levele Bereczky Alberthez. Kelt Basel, 1956. május 31. In: Pap László (1992): Tíz év és ami utána következett 1945-63. Adalékok a Magyarországi Református Egyház XX. századi történetéhez. Európai Protestáns Szabadegyetem kiadása, Budapest.

Bölöny József (1978): Magyarország kormányai 1848-1975. Akadémiai Kiadó, Budapest.

Tibori János (1995): A Tiszántúli Egyházkerület története 1944-1957. Magyar Református Egyház, Debrecen.

Tibori János (1996): A Tiszántúli Református Egyházkerület története 1957-65. Magyar Református Egyház, Debrecen.

Török István (1990): Határkérdések szolgálatunkban (1972-1989). Református Zsinati Iroda Sajtóosztálya, Budapest.

Fabiny Tamás (1992): Keken András életregénye. Plantin Kiadó, Budapest.

Hatos Pál (2016): Szabadkőmüvesből református püspök Ravasz László élete. Jaffa Kiadó, Budapest.

Poór József (1986): A protestáns teológia Magyarországon (1945-1985). Kossuth Kiadó, Budapest.

Ravasz László (1992): Emlékezéseim. Református Egyház Zsinati Irodájának Sajtóosztálya, Budapest.

Somogyország, 1957. május 26.

Szíj Rezső (1995): Az a hírhedt füredi beszéd. Szenci Molnár Társaság, Budapest. 